\title{
Implementation of Tikrar Methods in Memorizing Al-Qur'an in Tahfidzul Qur'an Foundation Al-Fawwaz Medan
}

\author{
Rahayu Budianti ${ }^{1}$, Mardianto ${ }^{2}$, Zulheddi $^{3}$ \\ ${ }^{1,2,3}$ Islamic Education of Universitas Islam Negeri Sumatera Utara, Medan, Indonesia \\ rahayubudianti47@gmail.com
}

\begin{abstract}
Muslims as a people who are given a holy book complete with all the instructions covering all aspects of life and universal, of course the basis of Islamic education is sourced from the philosophy of life based on the Qur'an. To protect the Qur'an one way is to memorize it.This research belongs to the type of qualitative research. The data used are primary data obtained through the process of extracting data by the method of documentation, observation and interviews. Data were analyzed by descriptive-qualitative method. As for checking the validity of the data using tringulation techniques.The results of this study indicate: (1) the planning process before memorizing the Qur'an is carried out various preparations including preparing media such as the Al-Qur'an Tikrar, designing an academic calendar and preparing a book of muktabaah. (2) Implementation of the tikrar method is carried out with the help of muhafidz/muhafidzah. The technical is to repeat the verse approximately 40 times according to the target after that, deposit it to muhafdiz / dzah. (3) the effectiveness of this method can be seen from the ease with which this method is applied in institutions because it is suitable for use by students at the elementary school level. legality of the institution. The inhibiting factor is indiscipline at the time of arrival. And the catching power of different santri. The solution to deal with these obstacles is by holding meetings with parents and giving punishment to students who are late.
\end{abstract}

\section{Keywords}

Tikrar Method; memorization of the Qur'an

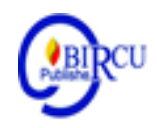

\section{Introduction}

Al-Qur'an is kalamullah revealed to the Prophet Muhammad, as an extraordinary miracle beyond the limits of human ability. One proof of the Qur'an is not human work is the preservation of lafadz and its meaning. Surah, verses and even letters will not change. Allah SWT. which maintains the authenticity of the Qur'an. Unlike the previous holy books, this can happen first and foremost because there is a guarantee from Allah Almighty: "Verily, I am the one who sent down az-Zikr (Al-Qur`an) and in fact We really maintain it (QS Hijr 15: 9).

Thus Allah Most High guaranteeing the versatility of the Qur'an, the guarantee given on the basis of His omnipotence and omniscience and the blessing of the efforts made by His creatures. As was done by the companions both when the Prophet lived or after his death and by the next generation. We can see these efforts starting from the Prophet as a person who is trying to memorize the verses of the Qur'an revealed by Allah. through the angel Gabriel. 
Each time the Messenger of Allah (saw) had finished receiving the revealed verses, He read them to the Companions and ordered them to memorize and to certain Companions ordered by the Apostle to write on the fronds of the palm, bones, animals, on rocks and on the skin- animal skins and other means. Such is the earnest and love of the Companions trying to memorize and record the Qur'an.

It was only afterwards that during the time of Ustman bin Affan the bookkeeping of the Qur'an was perfected by compiling letters in accordance with the provisions of the Messenger of Allah and writing them in a writing system that accommodated all the correct qira at. So the preservation of Allah. Towards Al-Qur`an does not mean that Allah Almighty is guarding the phases of the writing of the Qur'an directly, but Allah involves His servants to participate in guarding the Qur'an by memorizing. Therefore memorization culture has always existed, and the memorizers of the Qur'an are people chosen by Allah. to guard the Qur'an.

The high awareness of Muslims to memorize the Al-Qur`an reinforces the Al-Qur`an as the most memorized holy book. Muslims memorize verse by verse, surah by surah and juz by juz then store it in their chests. The memorizers of the Al-Qur'an in memorizing the Al-Qur'an certainly experienced obstacles in memorization, one of them for the level of children $\mathrm{Sd}$, the memorizers often have difficulty in memorizing verses and the difficulty of improving the quality of memorization especially in terms of fluency. For that it takes murajaah or repetition of memorization that has been memorized so that it sticks in memory. In addition, to achieve the objectives needed a method and a suitable way to achieve the desired goals.

One suitable method is the tikrar method. The tikrar method is a systematic form of memorizing the Qur'an which is the oldest and most widely practiced by the huffaz (memorizing the Qur'an) from the past until now. Especially with the existence of the AlQur'an Tikrar itself, making it easier for children to memorize verse by verse and surah by surah. In its understanding the tikrar method means repeating reading.

Tahfidzul Qur`an Foundation Al-Fawwaz Medan is the Tahfidzul Qur`an foundation that uses the tikrar method in memorization. Judging from the condition of all students santri certainly need special attention in maintaining the smooth memorization. Because based on facts on the ground (Yayasan Tahfidzul Qur`an Al-Fawwaz Medan) must be good at dividing time between school work and muroja'ah in order to maintain the smoothness of memorization, one of them is by applying the tikrar method. The more often you say it the stronger you remember it.

To that end, researchers are interested in conducting in-depth research to find out the extent of the implementation of the tikrar method in memorizing Al-Qur`an at the Tahfidzul Qur`an Foundation Al-Fawwaz Medan,

\section{Review of Literature}

Etymologically Al-Qur'an is mashdar (infinitive) of Qara'a - Yaqra-u - Qira-atan Quraa-nan which means reading. Al-Qur'an in the sense of this reading, for example, is contained in the word of Allah Almighty: When we have finished reading it, then follow the reading. (QS Al-Qiyamah: 17-18).

According to some scholars such as Imam Shafi'i, as quoted as-Suyuthi, the Qur'an is ism 'ghairu musytaq (a name that has no origin), is a special name for the word of Allah. revealed to the Prophet Muhammad SAW as well as the Torah and the Gospel which also has no origin. If the Qur'an comes from the word qara-a it means that everything that is read can be named the Qur`an. 
In terminology, Yunahar Ilyas (2013: 16) says the Qur'an is: "The Word of God Almighty. which was revealed to Muhammad SAW, who reads with worry and worship by reading it ". Meanwhile, according to Muhammad Amin Suma (2014: 25) Al-Qur'an AlQur'an is the word of Allah Almighty which was revealed to the Prophet Muhammad in the form of Arabic pronunciation with the intermediary of the Angel Gabriel who was quoted to us by muthat, beginning with the surah Al-Fatihah and ending with Surah An-Nas and written in the Mushaf.

In his book The Fundamentals of Al-Qur'an Manna Al-Qathan also states (2017: 32) Al-Qur`an comes from the word Qara'a means to unite and combine. Al-Qira ah means combining letters and words with each other while reading. Al-Qur'an is basically the same as the word al-qira ah, the mashdar form of the word qara`a-qira`atan-qur`aanan.

Etymologically memorizing comes from the basic word memorized which in Arabic is called Al-Hafidz which means to remember. Then the word memorization can also be interpreted by remembering. Whereas in terms of memorization has meaning as an act that seeks to absorb into the mind so that it is always remembered. (Kholidul Imam, 2016: 14).

According WiDwi Mukhobibah (2017: 201) Memorizing the Qur'an can be explained as a process of Encoding (encoding), storing (storing), and retrieving (recalling or taking back) verses of the Qur'an by practicing and repeating the verse many times.

As according to Siti A Toyibah (2017: 191) in essence memorizing is the first step for Muslims to always remember the verses of the Qur'an so that it can be as often as possible to remember Allah. In addition, memorizing the Qur'an can provide prosperity in life, because the Qur'an is an antidote, grace, healer and source of happiness for all Muslims in the world.

Memorization of the Qur'an is to recite so that it memorizes from one verse to the next, from one letter to another and so on so that it reaches thirty juz. According to Badwilan (2009: 27) in memorizing the Qur'an requires its readers to be repeated, and reinforcement of memorization requires continuous repetition. While being more serious views that memorizing the Qur'an is the one who memorizes the pronunciations, then it must also understand its meanings and practice the instructions so that it truly becomes the bearer of the truth value of the pronunciations.

According to Zuhairini and Ghofur (2004: 76), memorization is a method used to recall something that was read correctly as it is. The method is widely used in efforts to memorize the Qur'an and the Hadith. There are four steps that need to be done in using this method, including:

1. Reflecting, namely paying attention to the material being studied, both in terms of writing, punctuation and signals.

2. Repeating, i.e. reading and following repeatedly what is said by the teacher.

3. To recite, which is to repeat individually to show the results of learning about what is learned.

4. Retention, i.e. memories that are held about what has been learned are permanent.

With this understanding, memorizing the Al-Qur'an is the process of planting material in the form of verses, letters in the Al-Qur'an in memory and can produce it back in verbal form. People who memorize the Qur'an then forget part or all of it because of disparaging or careless without a reason, it is not called hafiz and has no right to bear the title of "memorizing the Qur'an".

So, according to the author memorizing the Qur'an is a noble deed, because people who memorize the Qur'an must know and know how the memory works because of the memory they have because it is very important in memorizing life. Because with that memory humans can even be able to reflect on themselves. 
include:

According to Badwilan (2009: 24) the virtues or urgency of memorizing the Qur'an

1. Become the family of Allah.

2. Can give syafa at to the family.

3. The memorization of the Qur'an will wear a crown of honor.

4. Parents get a special reward if their children memorize the Qur'an.

5. They (for men) are more entitled to become priests in prayer.

According to Saeid al-makhtum and Yadi Iriadi (2018: 49) There are several steps to memorize the Qur'an that must be taken for memorizers. Among others: (1) straighten intention, (2) strengthen determination, (3) relieve time, (4) pray and resignation, (5) start with the easiest, (6) focus, (7) determine the target, and (8) rote memorization

As for making it easier to memorize the Qur'an, the method is needed to memorize. There are many methods including:

\section{Wahdah Method}

Namely memorizing one by one against the verses that want to memorize. To reach the initial rote, each verse can be read ten times, or twenty times, or more so that this process is able to form patterns in its shadows. After really memorizing, then proceed to the next verses in the same way, and so on until reaching one face. So that the more is repeated, the quality of memorization will be more representative.

2. Khitabah Method

Khitabah means writing. In this method the writer writes first the verses he will memorize on a piece of paper. Then the verses are read until they are smooth and correct reading, allu memorized. How many verses are written depends on the ability to memorize. Maybe one verse is enough. If it turns out the turn of the verse that must be memorized belongs to the long group of verses. It could also be 5 or up to 10 verses, if the verses that are memorized include the verses of the dexterator as contained in short letters. This method is quite practical and good, because in addition to reading verbally, the visual aspect of writing will also be very helpful in accelerating the formation of memorization and shadow patterns.

3. Sima'i Method

Sima'i means to hear. This method is by listening to a reading to memorize it. This method will be very effective for memorizers who have extra memory, especially for memorizers who are blind, or children who are under age who do not know how to read and write the Qur'an.

4. Combined Method

This method is a combination of the Wahdah method and the Biblical method. The advantage of this method is the dual function, which is to memorize and at the same time be prestigious for memorizing memorization because by writing it will give a visual impression that is good.

According to Iskandar (2015: ) Tikrar method or repetition is a method of memorization that is done by repeating the part you want to memorize. Repetition makes the process of increasing discipline in managing time. As for the types of application of the tikrar method according to Sa'dullah (2008: 68) are: (1) Takrir himself, (2) Takrir in prayer, (3) Takrir together, and (4) Takrir before the teacher

The disadvantages of this method are: (1) When an error occurs in repeating memorization on its own, then no one justifies the error, the error can only be changed to be true if the memorizer is aware that there is an error in memorizing the verses of the Qur'an, and (2) Requires a long time, must continuously repeat. People who memorize the Qur'an must be prepared to keep repeating the rote.

The advantages of this method are: 
1. Correct mistakes in reciting verses, so that they can recite verses correctly in accordance with the meaning of the letters and the proper knowledge of recitation. Because sometimes if you repeat yourself there are mistakes that are not realized. It would be different if it involves a partner/teacher, the mistakes that occur will be easily known and then corrected.

2. Strengthening memorization that has been memorized.

3. Improve memory, when a person memorizes the Qur'an repeating a verse that he memorized, when that also the percentage strength of his memory will increase.

4. Repetition makes the process of memorization faster and able to last a long time in memory.

\section{Research Method}

The research method used is a qualitative research method which research is not intended to test certain hypotheses, but only describe "what it is" about a variable, symptom or condition. The data used are primary data obtained through the process of extracting data by the method of documentation, observation and interviews. Data were analyzed by descriptive-qualitative method. As for checking the validity of the data using tringulation techniques.

\section{Discussion}

In the planning process before memorization is done, at the Tahfidzul Qur'an Foundation Al-Fawwaz performs perispan, including preparing children's mentality by looking at the backgrounds of santri families, preparing correct intentions and sincerity to memorize Al-Qur`an, preparing tahfidz media in the form of Al- The free tikrar quran, muktabaah books, and there is a preliminary test for mapping basic competencies owned by students, if prospective students have not passed the reading, they will be included in accordance with the prepared class, namely preparatory class, first class and second class. that every week a hadith class and a motivational class are made, it aims to form the morals of the students and arouse the motivation of the students, because motivation is the main supporting factor in memorizing the Qur'an.

The implementation of the tikrar method at the Tahfidzul Qur'an Al-Fawwaz Foundation includes several stages namely, firstly, Santri holds the al-Qur`an Tikrar each previously distributed by the foundation. Second, Santri repeats memorization more or less 40 times. Third, with the instruction and supervision of the teacher, students must mark each column that is printed on the Koran tikrar with five markings, each time reading, put a sign once. Marking can use a circular cross as explained in the above research findings. Fourth, Muhafidz gives a target by each student, to memorize in accordance with the ability to memorize and according to fluency in reading the Qur'an. Of course this is seen from the background of students reading before entering the memorizing level class. Of course this division is in accordance with the instructions of the Al-Qur'an tikrar. Which on each page is divided into 4 maqro 'and 8 maqtha'. After that, the students memorize in accordance with their respective targets by actually memorizing the first verse, students should not continue to memorize if the previous verse is not really memorized. After the students feel that they have memorized completely, then the students deposit their memorization with the muhafidz / zhah face to face, muhafidz listens to the memorization that the students deposit by marking verses / readings in the Koran when the students are wrong in their 
pronunciation. After a student has memorized the target for example $1 \mathrm{juz}$, then memorized the student will be in tasmi 'in front of his friends as well as his muhafidz/dzah.

The effectiveness of the tikrar method is applied in the Tahfidzul Qur'an Al-Fawwaz Foundation, as seen from the implementation of the tikrar method on a daily basis. The memorization activity at this institution was effective by applying this method of tikrara, the results of the memorization of students increased, not only seen from the memorization value that reached mumtaz but their reading and fluency were good. As for the achievement of students in Juz 29 as many as 12 people and juz 1 as many as 2 people, and those who get the Mumtaz category score as many as 8 people, and toyyib as many as 6 people. This is influenced by the method of tikrara which is easy to be applied by students at the elementary school level.

Supporting and inhibiting factors in the implementation of the tikrar method at the Tahfidzul Qur'an Al-Fawwaz Foundation are the internal factors of the children themselves in the form of enthusiasm in memorizing, the factor of full support of teachers and caregivers, ease of using methods, legality of the institution, support from local community leaders and completeness tahfidz media. While the inhibiting factors are the different backgrounds of santri families so it is difficult to regulate, the lack of discipline, especially at the time of arrival, as well as the different attractiveness of students. But the solution used to overcome these obstacles is the foundation makes a policy by holding parents' meetings in every midsemester aimed at discussing the problems of their children's development, besides the holding of punishment for students who violate rules.

\section{Conclusion}

Based on the research that has been done and described above, it can be concluded that the Implementation of the Tikrar Method in memorizing Al-Qur'an in the Tahfidzul Qur'an Foundation Al-Fawwaz runs well according to the guidelines of the Tikrar method itself. Judging from the start of the planning process (preparing academic calendars, media, etc.), the implementation process that is in accordance with the guidelines for using the method, the result is that many students reach rote targets with the predicate mumtaz and toyyib values, while the supporting factors are the completeness of the media provided by the institution and the ease of the tick method it is applied, while the obstacle is the indiscipline of santri in attendance, one solution is to make punishment and hold a meeting of santri trustees.

My advice that can be delivered is to improve the personal qualities of educators in advancing the Tahfizul Qur'an Al-Fawwaz Foundation with good management, always Istiqomah in conveying the truth and memorizing and preserving the Qur'an, because the Qur'an will be stored in chest of someone who is still istiqomah and sincere in maintaining rote learning.

\section{References}

Al- Qatthan, Manna. Dasar-Dasar Ilmu Al-Qur`An. Jakarta: Ummul Qura. 2017.

Al-Ghautsani , Yahya Bin Abdurrazaq. Cara Mudah Dan Cepat Menghafal Al-Qur`An. Jakarta: Pustaka Imam Syafii. 2013.

Al-Kaheel, Abdul Daim. Lantunan Qur'An Untuk Penyembuhan. Yogyakarta: Pustaka Pesantren. 2012. 
Al-Makhtum, Saeid Dan Yadi Iriadi. Karantina Hafal Qur`An Sebulan. Madura: CV.Alam Pena. 2018.

Ananda, Rusydi dan Amiruddin. Inovasi Pendidikan Melejitkan Potensi Teknologi Dan Inovasi Pendidikan. Medan: Widyapuspita, 2017.

Arikunto Suharsimi. Prosedur Penelitian. Jakarta: PT.Rineka Cipta, 2002.

Badwilan, Panduan Cepat Menghafal Al-Quran. Yogyakarta. Diva Press. 2009.

El Hafidz, Herman Syam. Siapa Bilang Al-Quran Itu Sulit. Yogyakarta: Pro U Media. 2015.

Hadari, Nawawi. Metode Penelitian Bidang Sosial. Yogyakarta: Gajah Madah University Pers. 2012.

Ilyas, Yunahar. Cakrawala Al-Qur`An. Yogyakarta: Suara Muhammadiyah. 2003.

. Kuliah Ulumul Qur`An. Yogyakarta: ITQAN Publishing. 2013.

Imana, Yudi. Panduan Aplikatif Sebulan Hafal 1 Juz Metode Tikrar Sekolah Dasar Juz 28. Bandung: PT Sygma Examedia Arkanleema. 2016.

Iskandar. Metode At-Takrar Untuk Meningkatkan Daya Ingat Para Hafidz Qur`An. 2015.

Kholidul Imam, Strategi Menghafal Qur`An (Studi Kasus Di Rumah Tahfidz Darul Quran Putra Kepanjangan Malang). 2016.

Mukhobibah,Widwi. Kesejahteraan Spritual Pada Mahasiswa Penghafal Al-Qur`An. Jurnal Studia Insania, Volume 5 NO 2. 2017.

Muslimin, Achmad. Implementasi Metode Halaqah Dan Resitasi Dalam Tahfidz Al-Qur`An Di SDIT El-Haq Banjarsari Buduran Sidoarjo. Volume 1 No 1. 2015.

Sa'dullah. 9 Cara Praktis Menghafal Al-Qur`An. Jakarta: Gema Insani. 2008.

Suma, Muhammad Amin. Ulumul Qur`An. Jakarta: PT Rajagrafindo Persada. 2014.

Syihab, M Quraisy. Tafsir Misbah. Jakarta: Lentera Hati. 2000.

Zuhairini Dan Abdul Ghofur, Metodologi Pembelajaran Dan Pendidikan Agama Islam. Malang: UM Press, 2004. 